\title{
Reduction of Environmental Pollution Applying Decentralised Wastewater Treatment Systems in Small Communities ${ }^{1}$
}

\author{
Tamás KARCHES ${ }^{2}$
}

\begin{abstract}
Small size wastewater treatment plants are widely used as a decentralised treatment solution in regions, where the access to the sewer system is not available or the connection to an existing system is not economically sound like in small communities (e.g. schools, hospitals, army camps, etc.). The local treatment of wastewater can be performed by small size units applying activated sludge or attached growth biomass. In this paper the performance and operation of a process unit applying conventional activated sludge is analysed. For this purpose, a simulation tool with mass balance modelling was used. In the model, various influent wastewater qualities were set in order to examine their effect on each process. Operational parameters were fine-tuned to increase the capacity by utilising additional aeration. As a result, it can be stated that the nominal capacity of the treatment unit is overestimated; in the Central European region, due to the wastewater characteristics, the examined treatment unit could handle $40 \%$ of the nominal capacity.
\end{abstract}

Keywords: activated sludge, decentralised system, mass balance modelling, sewerage, wastewater treatment

\section{Introduction}

The aim of the urban water management is to secure the quantity and quality of water provided to consumers. Public service has a high level of responsibility in ensuring water safety and sustainability. [1] When the urban water cycle is concerned, the wastewater collection and treatment system have a significant role to protect the receiving water bodies and water bases of water acquisition [2] even in extreme conditions caused by global warming. [3]

A general concept is to collect and transport wastewater to a large treatment plant (mainly situated in the outskirts of the municipalities), where physical, biological and chemical processes are responsible for the reduction of pollutants (basically organic matter

\footnotetext{
1 The work was created in commission of the National University of Public Service under the priority project PACSDOP-2.1.2-CCHOP-15-2016-00001 entitled “Public Service Development Establishing Good Governance” in the Egyed István Postdoctoral Program.

2 Ph.D., Associate Professor, National University of Public Service, Faculty of Water Science; e-mail: Karches. Tamas@uni-nke.hu; ORCID: 0000-0003-2347-3559
} 
and nutrients) in order to reach the effluent quality requirement. This system requires large external energy investments and thus increased operational costs via application of pumps, aeration and chemicals, but the space requirement is relatively small compared to the area of natural degradation processes.

Nowadays many decentralised wastewater treatment systems (DEWATS) are available, which serve the suburban low population density residential areas or industries with specific wastewater discharges, but are also feasible for small communities, hospitals, [4] schools, hotels and army camps. In army base camps, the closed cycles are important, therefore portable wastewater systems are one of the favourite and well-known applications. [5] [6]

Furthermore, DEWATS are widely used in developing countries, where the establishment of a sewer system is not attainable. For example, in the slum of Alam Jaya ${ }^{3}$ (Jakarta) a combination of community-sewerage sanitation system, shared septic tanks and community sanitation centres provide a basic level of sanitation. [7] [8]

Sizing a decentralised wastewater treatment unit is not a simple scale down design from a conventional plant. However, the core processes are the same, but the operation environment differs; e.g. a built-in aeration system is not always possible, the sludge management is basically reduced to the storage of the wet mass volume. A typical system combines the treatment steps in a modular manner; for primary treatment sediment ponds, settlers or septic tanks, for secondary treatment filters, facultative ponds or anaerobic baffled reactors, for post-treatment aerobic polishing ponds could be applied. [7]

The most conventional system applies a septic tank, which may handle the organic matter effectively, but the septic effluent shall be further treated if a nutrient removal is aimed. During this process a gravel filtration could reduce the nitrogen content by approximately $30 \%$ and the phosphorous content by 60\%. [9] Compact small size wastewater treatment units are also applied, which are often chemically intensified. The requisites of this system is modularity, easy operation and maintenance and efficient organic matter reduction at low cost.

Among the various DEWATS options, the small size treatment units or package plants are investigated in this study. The methodology section gives an insight into the numerical mass balance calculations and simulation environment, the result and discussion section details the influent characterisation of the influent wastewater, determines the capacities of each unit and presents the possibility of operational parameter adjustment.

\section{Materials and Methods}

The capacity of a Polydox-50 small size wastewater unit was analysed. The nominal capacity was $50 \mathrm{PE}^{4}$ and the hydraulic load was $6.0 \mathrm{~m}^{3} / \mathrm{d}$. The volume of the unit was $8.4 \mathrm{~m}^{3} / \mathrm{d} ; 70 \%$ of the volume was considered to be aerated and had aerobic conditions, the rest was designed for settling and sludge thickening. In order to predict the actual effectiveness of the system, mass balance modelling was carried out which was an effective tool in predicting treated

Industrial area with a high crime rate, low living standards, no social network and healthcare system.

PE - Population Equivalent. 
wastewater quality. GPS-X $6.5^{5}$ commercial simulation environment was applied, where the biological model of ASM2 $\mathrm{d}^{6}$ was set.

This model presents the results of the processes of organic degradation and nutrient removal in municipal wastewater discharges. [10] The model is based on a set of mass transport equations and the fate of a pollutant component is determined by reaction kinetics, which can be decomposed to biokinetic processes. Each process can be taken into account by the reaction rates and stoichiometric parameters. The ASM2d model applies approximately 60 conversional and stoichiometric parameters, and yields half-saturation coefficients. [11]

The process scheme of the treatment unit can be seen in Figure 1, which presents each process and the mass flows between them (lines). Raw wastewater is discharged to an equalisation tank (EQ tank), followed by the biological processes, which is an activated sludge system (CAS). ${ }^{7}$ The dosage of external carbon source is possible if necessary (if the carbon to nitrogen concentration ratio is lower than 5). The clarifier is responsible for settling, the settling efficiency is based on the solid loading rate, which is determined by the mixed liquor concentration in the biological basin and the hydraulic load. The sludge dewatering unit in the model is responsible for the storage of the sludge, where a small amount of leachate is directed back to the biology. The solid capture of this unit is approximately 5\%.

The model layout drawn in Figure 1 does not indicate the sizes, dimensions and operating parameters; flows and the dissolved oxygen concentration in the aerated basins have to be set prior to the simulation process.

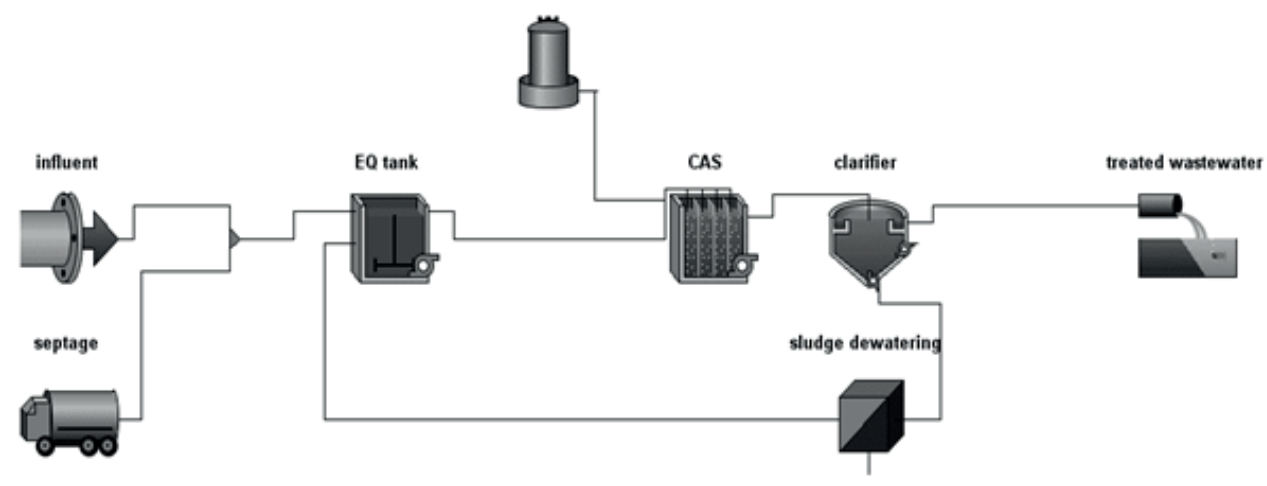

Figure 1. Model layout of an activated sludge small size wastewater treatment unit. [Edited by the author.]

The model approach assumes steady-state conditions and average wastewater influent constituents. Two sets of raw wastewater influent data were analysed, one with an average concentration, which is typical for Central Europe and another tier of data with elevated concentrations, which is typical to regions, where the water consumption is decreased. The composite wastewater parameters are summarised in Table 1.

\footnotetext{
5 GPS-X 6.5 is a software released by Hydromantis and it is a simulation environment incorporating various wastewater treatment models and approaches.

$6 \quad$ ASM2d - Activated Sludge Model version 2 with denitrification processes.

7 CAS - Conventional Activated Sludge.
} 
T. KARCHES: Reduction of Environmental Pollution Applying Decentralised Wastewater Treatment...

Table 1. Influent wastewater characteristics.

[Edited by the author.]

\begin{tabular}{|l|c|c|}
\hline $\mathbf{m g} / \mathbf{l}^{8}$ & Average influent & Strong influent \\
\hline COD & 750 & 1200 \\
\hline BOD $_{5}$ & 310 & 650 \\
\hline TSS & 400 & 800 \\
\hline TKN & 80 & 100 \\
\hline TP & 12 & 18 \\
\hline
\end{tabular}

The simulation steps were the following: influent wastewater characterisation, determination of model parameters and initial values for model variables, transferring the physical model setup to numerical model, performing calculations and evaluation of the result. [12] First the effluent quality was determined at nominal load. Then sensitivity analysis was performed and the effluent quality was calculated in function of the varying hydraulic loads. From this the optimal load could have been seen and lastly a steady-state simulation was performed at this optimal loading condition and the actual treated wastewater quality was determined. This process was done twice; with the average and the strong influent.

\section{Result and Discussion}

\section{Influent characterisation}

Influent fractionation is a key element in process modelling, since all of the model variables (both composite and state variables) cannot be determined by a physical measurement. Among the various fractionation methods, the COD-TSS based approach was selected and the COD fractions were the following for the average influent: inert organic COD: $16 \mathrm{mg} / \mathrm{l}$, readily biodegradable COD: $62 \mathrm{mg} / \mathrm{l}$, particulate inert COD: $270 \mathrm{mg} / \mathrm{l}$ and slowly biodegradable COD: $402 \mathrm{mg} / \mathrm{l}$. The substrate fraction of particulate COD was 0.6 and the organic content of TSS was 0.8 . This values for the strong influent wastewater were the following: inert organic COD: $24 \mathrm{mg} / \mathrm{l}$, readily biodegradable COD: $96 \mathrm{mg} / \mathrm{l}$, particulate inert COD: $194 \mathrm{mg} / \mathrm{l}$, slowly biodegradable COD: $886 \mathrm{mg} / \mathrm{l}$. The substrate fraction of particulate COD was 0.82 and the organic content of TSS was 0.75 .

In both cases, the readily biodegradable content is relatively low compared to other components, and the particulate fractions are high, resulting slower degradation processes, since the particulate matter shall undergo a hydrolysis before microorganism uptake. This may have a consequence that a certain reactor volume may have a lower capacity than it is expected.

8 COD - Chemical Oxygen Demand; $\mathrm{BOD}_{5}-$ Biological Oxygen Demand; TSS - Total Suspended Solid; TKN - Total Kjeldahl Nitrogen (ammonium and organic N-content); TP - Total Phosphorous. 
T. KARCHES: Reduction of Environmental Pollution Applying Decentralised Wastewater Treatment...

\section{Calculation of the treatment unit performance}

Applying the influent characteristics, steady-state simulation was performed with the nominal raw wastewater discharge $\left(6.0 \mathrm{~m}^{3} / \mathrm{d}\right)$. The dissolved oxygen concentration was $2.0 \mathrm{mg} / \mathrm{l}$ in the aerated basin. As a result, the sludge production was $1.35 \mathrm{kgTS} / \mathrm{d}^{9}$ at $0.78 \%$ dry solid content. The thickened and dewatered sludge quantity is $6.4 \mathrm{l} / \mathrm{d}$. From the calculations it can be clearly seen that the nitrogen removal is not sufficient if the nominal capacity is used (COD: $50 \mathrm{mg} / \mathrm{l}$, TSS: $24 \mathrm{mg} / \mathrm{l}, \mathrm{NH}_{4}-\mathrm{N}: 25 \mathrm{mg} / \mathrm{l}$, TN: $\left.27 \mathrm{mg} / \mathrm{l}\right)$. Full nitrification is achieved only if the ammonium-nitrogen is converted to an oxidised form, but in this case the nitrification is partial.

As a next step, the raw wastewater discharges were varied and the flow was determined, where the nitrification was acceptable. The result of the analysis can be seen in Figure 2, where the effluent COD (grey) and ammonium-nitrogen (black) variation can be seen in function with the actual discharge. It is demonstrated that there is a breakpoint, where the ammonium-nitrogen concentration increases sharply and the treated water effluent quality is getting far from the effluent quality requirement. This breakpoint is at about $2.5 \mathrm{~m}^{3} / \mathrm{d}$ flow, which is less than half of the nominal capacity. The reason could be the fact that these units are designed for the treatment of weaker raw influent, assumes higher water consumptions of the households, which may be valid for Western Europe, USA, Australia, but not valid for Central Europe and regions in Asia and Africa.

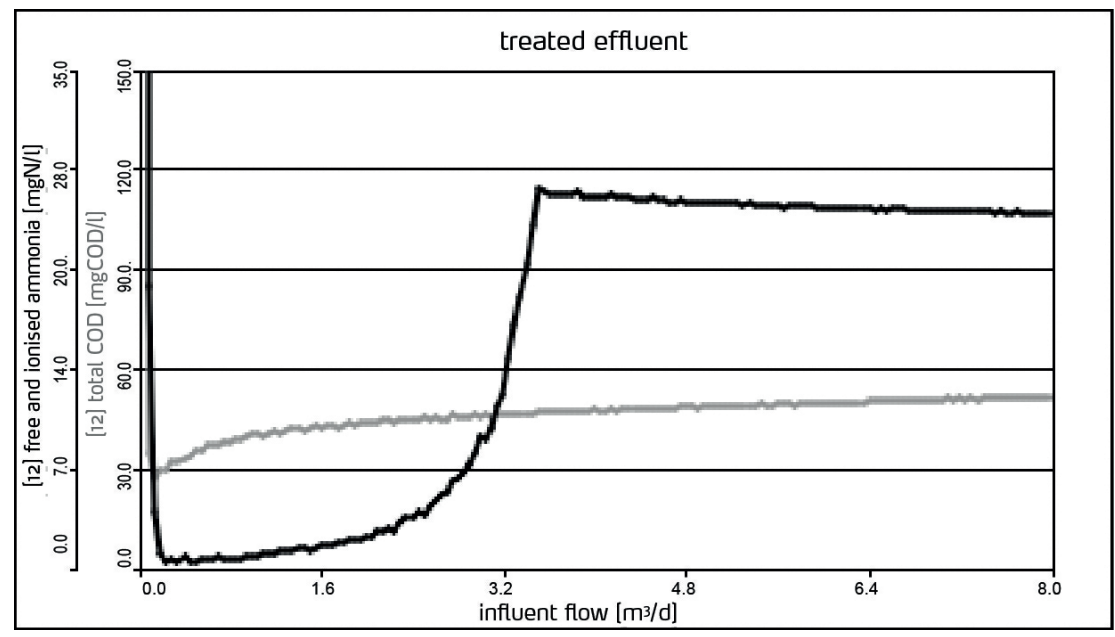

Figure 2. Effluent total COD ( $\mathrm{mg} C O D / \mathrm{l})$ and free and ionised ammonia $(\mathrm{mgN} / \mathrm{l})$ concentrations in function with the influent flow.

[Edited by the author.]

As Figure 2 shows there is no sharp increase in the COD effluent curve. The reason could be that a large proportion of COD is in particulate form. An increase of the load does not

9 Daily Total Solid Production. 
T. KARCHES: Reduction of Environmental Pollution Applying Decentralised Wastewater Treatment...

require biological capacity, just a buffer in the settling process, which is available in this system.

As a part of the calculation, the strong wastewater influent was also assumed. At this condition, full nitrification was impossible to be achieved. Instead of a further capacity reduction, the operational parameter was adjusted. If the aeration intensity is increased to reach the DO level of $3.5 \mathrm{mg} / \mathrm{l}$, nitrification becomes acceptable. This meant a 30\% increase in the aeration requirement.

\section{Conclusion}

Decentralised wastewater treatment systems are alternative solutions for sanitation. In geographies without a sewer system, it could treat wastewater locally. A wide variety of technologies and processes have been developed. The selection shall be based on the local circumstances and the wastewater quality and quantity. Small size treatment units can be applied, but before the selection, it is advisable to perform mass balance calculations to predict the actual capacities of such a system; the theoretical and actual capacity may differ significantly.

The overall conclusion of this research is that the nominal capacity of the investigated small size wastewater treatment unit is overestimated in both cases: the unit could treat $40 \%$ of the wastewater effectively, indicating that instead of the original $50 \mathrm{PE}$ it could handle $20 \mathrm{PE}$ if it is applied in Central Europe, and the influent comes from communal source. It was also concluded that the operation could help in capacity increase, but it requires energy and a resulting operational cost increase.

\section{References}

[1] BEREK T.: Water Safety Plan's Roll in the Sustainable Water Management. Múszaki Katonai Közlöny, 262 (2016), 32-48.

[2] CSŐSZ L.: Domestic Status of the Range of Problems Related to Water Quality Protection. Hadmérnök, 131 (2018), 168-177.

[3] KUTI R. - NAGY, Á.: Weather Extremities, Challenges and Risks in Hungary. AARMS, 14 4 (2015), 299-305.

[4] NAINGGOLAN, C. M. U. - PERMANASARI, V. Y.: Cost Effectiveness and Efficiency Analysis of Hospital Wastewater Treatment Plant: A Systematic Review. Proceedings of the International Conference on Applied Science and Health, 1 (2017), 128-135.

[5] GONZALES, J. S.: Portable wastewater systems: integration into army missions. International Journal of Critical Infrastructures, 310 (2014), 30-38. DOI: https://doi. org/10.1504/ijcis.2014.059542

[6] MEDINA, V. F. - WAISNER, S. A.: Military Solid and Hazardous Wastes-Assessment of Issues at Military Facilities and Base Camps. Waste, Elsevier Publisher, 2011. DOI: https:// doi.org/10.1016/b978-0-12-381475-3.10025-7

[7] ULRICH, A. - REUTER, S. - GUTTERER, B.: Decentralised Wastewater Treatment System (DEWATS) and Sanitation in Developing Countries: A Practical Guide. 
T. KARCHES: Reduction of Environmental Pollution Applying Decentralised Wastewater Treatment...

Loughborough, Loughborough University of Technology Water, Engineering and Development Centre (WEDX), 2009. https://sswm.info/sites/default/files/reference_ attachments/DEWATS_Guidebook_small.pdf (Downloaded: 24.10.2018)

[8] GUTTERER, B. - SASSE, L. - PANZERBIETER, T. - RECKERZÜGEL, T.: Decentralised Wastewater Treatment (DEWATS) and Sanitation in Developing Countries. Bremen, BORDA, 2009.

[9] MAGDOFF, F. R. - KEENEY, D. R. - BOUMA, J. - ZIEBELL, W. A.: Columns Representing Mound-type Disposal Systems for Septic Tank Effluent II. Nutrient Transformations and Bacterial Populations. Journal of Environmental Quality, 3 (1974), 228-234. DOI: https://doi.org/10.2134/jeq1974.00472425000300030009x

[10] HENZE, M. - GUJER, W. - MINO, T. - MATSUO, T. - WENTZEL, M. C. MARAIS, G. - LOOSDRECHT, M. C.: Activated Sludge Model No. 2. Water Science and Technology, 391 (2009), 165-182. DOI: https://doi.org/10.1016/s0273-1223(98)00785-9

[11] KARCHES T.: Effect of Internal Recirculation on Reactor Models in Wastewater Treatment. WIT Transactions on Ecology and the Environment, 228 (2018), 145-153. DOI: https://doi. org/10.2495/wp180151

[12] KARCHES T.: Sewage Treatment Plant Upgrade Applying Wastewater Process Simulation. International Journal of Engineering Research and Development, 145 (2018), 22-26. 